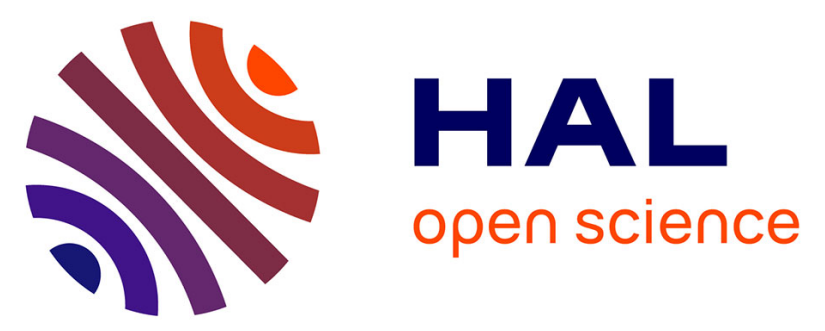

\title{
An Integrated Apricot Breeding Program in France Joining CEP Innovation - CENTREX and INRA
}

Jean Marc Audergon, Alain Blanc, Frederic Gilles, Guy Clauzel, Jean Michel

Broquaire, Barbara Gouble, Marie Grotte, Maryse Reich, Sylvie Bureau, Guillaume Frémondière, et al.

\section{To cite this version:}

Jean Marc Audergon, Alain Blanc, Frederic Gilles, Guy Clauzel, Jean Michel Broquaire, et al.. An Integrated Apricot Breeding Program in France Joining CEP Innovation - CENTREX and INRA. 15. International Symposium on Apricot Breeding and Culture, Jun 2011, Yerevan, Armenia. 2011. hal-02746028

\section{HAL Id: hal-02746028 \\ https://hal.inrae.fr/hal-02746028}

Submitted on 3 Jun 2020

HAL is a multi-disciplinary open access archive for the deposit and dissemination of scientific research documents, whether they are published or not. The documents may come from teaching and research institutions in France or abroad, or from public or private research centers.
L'archive ouverte pluridisciplinaire HAL, est destinée au dépôt et à la diffusion de documents scientifiques de niveau recherche, publiés ou non, émanant des établissements d'enseignement et de recherche français ou étrangers, des laboratoires publics ou privés. 
